\title{
The Activity Pattern of Overwintering Indian Rock Pythons, Python molurus (Linnaeus 1758) in a Semi-arid Region of India
}

\author{
Chinnasamy Ramesh ${ }^{1}$ and Manokaran Kamalakannan ${ }^{2}$
}

${ }^{1}$ Department of Population Management, Capture \& Rehabilitation, Wildlife Institute of India, Dehradun-248001, Uttarakhand, India (ramesh.czoo@gmail.com) ${ }^{2}$ Zoological Survey of India, Kolkata-700053, West Bengal, India

$\mathrm{T}$ emperature is a fundamental factor in the ecology of animals (Huey 1982), which in reptiles influences both behavior and physiology (Shine and Lambeck 1985; Brown and Weatherhead 2000). Thermoregulation can be behavioral or physiological; the former includes activities like emergence, retreat, basking, orientation, aggregation, and postural changes, whereas the latter comprises evaporative cooling, vasomotor responses affecting rates of heating and cooling (Brattstrom 1965), and limited heat production in brooding Python molurus (Ramesh and Bhupathy 2010). The very survival of reptiles is dependent on their ability to maintain heat balance (Lillywhite 1987; Withers 1992) in order to maxi-

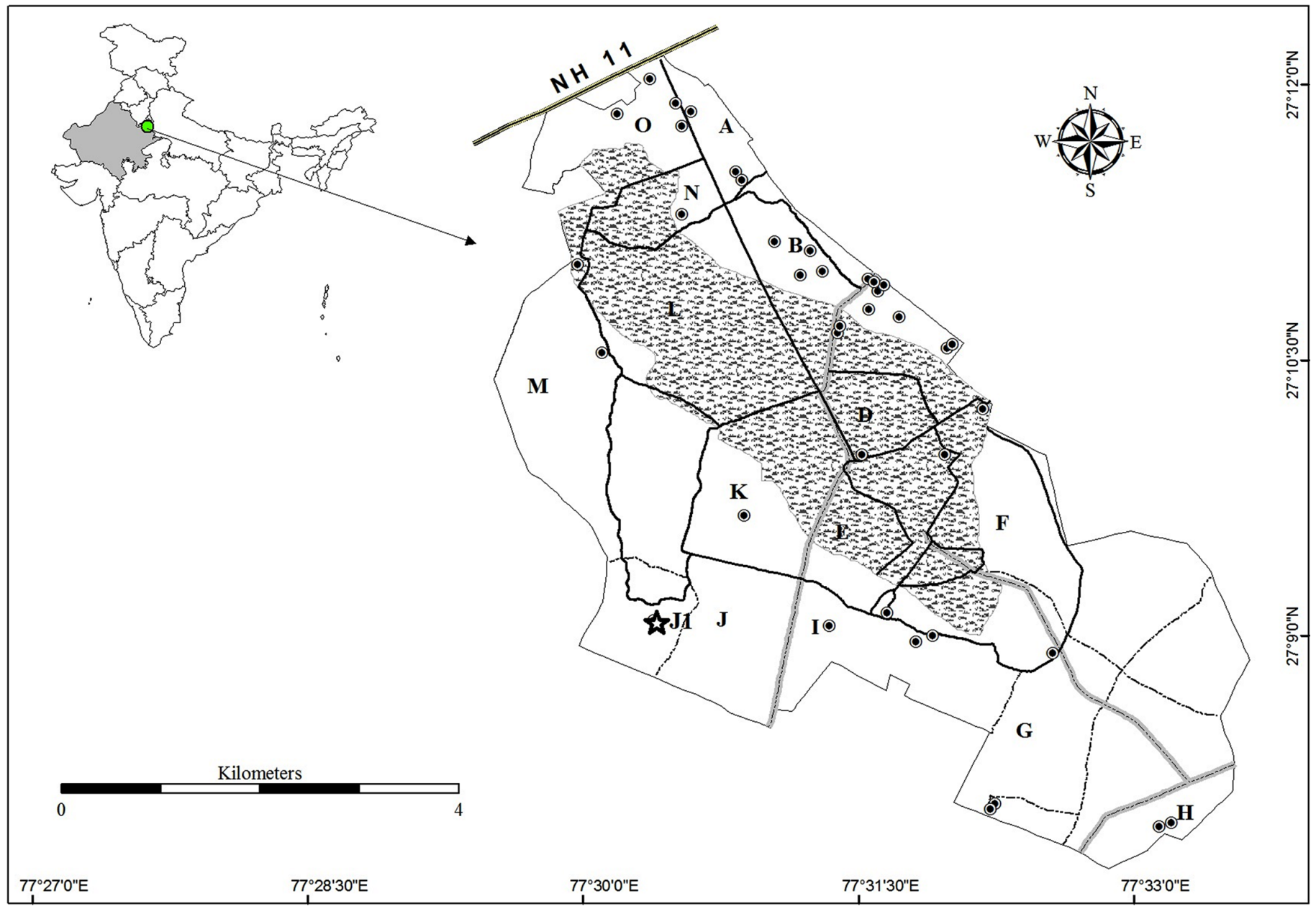

Fig. 1. Distribution of Indian Python (Python molurus) burrows in Keoladeo National Park, Rajasthan, India. Letters indicate the compartments of the park. Dots indicate burrows used by pythons. The star marks the burrow at which the observations described in this study were recorded. 
mize physiological performance (Avery 1982; Huey 1982) while employing behavioral and physiological thermoregulatory strategies (Huey et al. 1977; Rismiller and Heldmaier 1988; Slip and Shine 1988; Shine and Fitzgerald 1996; Werner et al. 2005). By actively responding to spatiotemporal characteristics of their environments, they are able to exploit varied and changing habitats (Hutchison and Maness 1979).

Reptiles are not active continuously but rather have discreet activity periods (Harker 1958), with daily and seasonal activity influenced by environmental temperatures (Porter et al. 1973). Activity patterns change according to thermal requirements, so studies of thermoregulation and activity patterns can provide insights into ecology, ecophysiology, and the spatiotemporal organisation of behaviors (Landreth 1973; Shine 1979; Semlitsch et al. 1981; Dalrymple et al. 1991). High activity temperatures are adaptive for reptiles in habitats that allow relatively easy access to abundant sunlight (Avery 1982) and, although climatic factors such as humidity and cloud cover do not show any general relation with the activity pattern of snakes, they can affect some species-specific ecological relationships (Stewart 1965; Shine and Lambeck 1985).

Studies of activity patterns have focused primarily on diurnal lizards; consequently, data on the activity of tropical snakes is lacking (Reed and Rodda 2009), although extensive studies on brooding python thermal biology are available (Ramesh and Bhupathy 2010; Stahlschmidt and Denardo 2010; Stahlschmidt et al. 2012; Brashears and Denardo
2015). Snakes generally exhibit seasonal variations in movement and activity patterns (Slip and Shine 1988; Heard et al. 2004). Recognizing the basis for daily, seasonal, inter- and intraspecific variations in movements and activity patterns is essential for understanding the ecology of species (Madsen and Shine 1998; Bonnet et al. 1999; Brown and Shine 2002). Information on the thermoregulatory behavior and thermal physiology of pythons in natural habitats is scanty (Alexander 2007; Reed and Rodda 2009; Mazzotti et al. 2011). Herein we describe activity patterns, such as basking, ingress, and egress, of Python molurus during a winter-to-summer thermal gradient in India.

\section{Methods}

We conducted this study in Keoladeo National Park, Bharatpur (KNP; $27^{\circ} 10^{\prime} \mathrm{N}, 77^{\circ} 31^{\prime} \mathrm{E}$; Fig. 1). This World Heritage and Ramsar Site has an area of about $29 \mathrm{~km}^{2}$ including $8.5 \mathrm{~km}^{2}$ of wetland. Dominant vegetation is a mixture of xerophytic and semi-xerophytic species such as Gum Arabic Trees (Acacia nilotica), Mustard Trees (Salvadora persica), Bada Peelu Trees (S. oleoides), Karir Trees (Capparis decidua), and Wild Caper Bushes (C. sepiaria) (Prasad et al. 1996), although the terrestrial vegetation has been altered profoundly by the proliferation of invasive Mesquite (Prosopis juliflora) despite control measures initiated by the Rajasthan Forest Department in 2007. The climate is sub-humid to semi-arid, with mean monthly maximum temperatures varying between

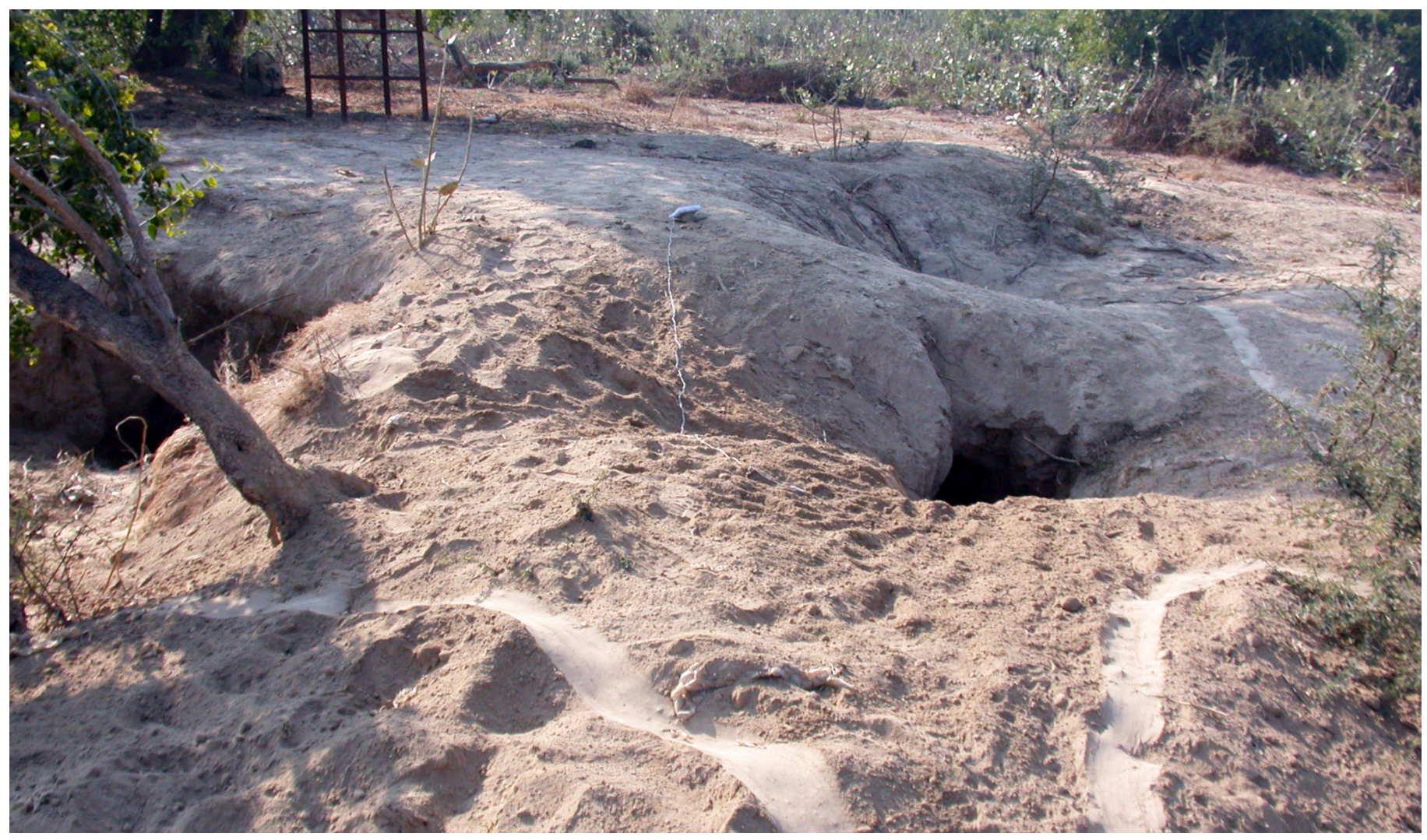

Fig. 2. Indian Python (Python molurus) tracks at the entrances of the burrow in Keoladeo National Park, Rajasthan, India. Photograph by Chinnasamy Ramesh. 
30.8 and $35.1^{\circ} \mathrm{C}$ and mean monthly minimum temperatures between 16.9 and $22.4^{\circ} \mathrm{C}$ (Ramesh 2012). Extreme temperatures recorded in the park range from one to $49^{\circ} \mathrm{C}$ with strong diurnal and seasonal variations (Prusty et al. 2007). The monsoon season extends from late June to September, and the average rainfall in Bharatpur is $655 \mathrm{~mm}$ (Ramesh 2012). Descriptions of ecological conditions in KNP (and of resident Python molurus) are in Bhupathy and Vijayan (1989), Ramesh and Bhupathy (2010, 2013), and Bhupathy et al. (2014).

Indian Rock Pythons (Python molurus) are large, heavy-bodied, non-venomous ambush foragers that reach snout-vent lengths of 6-8 m (Bhupathy 1990). This species is protected under Schedule I of the Indian Wildlife (Protection) Act of 1972. They occupy diverse habitats on the Indian Subcontinent and can be found in dry regions, wetland areas, and forests ranging from xeric scrub to rainforests (Kamalakannan 2009). They are semi-arboreal and prey upon a variety of small to medium-sized mammals, birds, and lizards (Bhupathy et al. 2014). Their activity pattern is unimodal during winter and bimodal in spring and summer in the semi-arid conditions that prevail in KNP (Bhatt and Choudhury 1993). Ramesh (2012) estimated that 100-200 adults live in KNP.

In KNP, pythons live in underground burrows dug by Indian Porcupines (Hystrix indica). Burrows provide safe retreats from predators and extreme weather conditions. Fifty refugia were documented (Fig. 1) when a python or signs

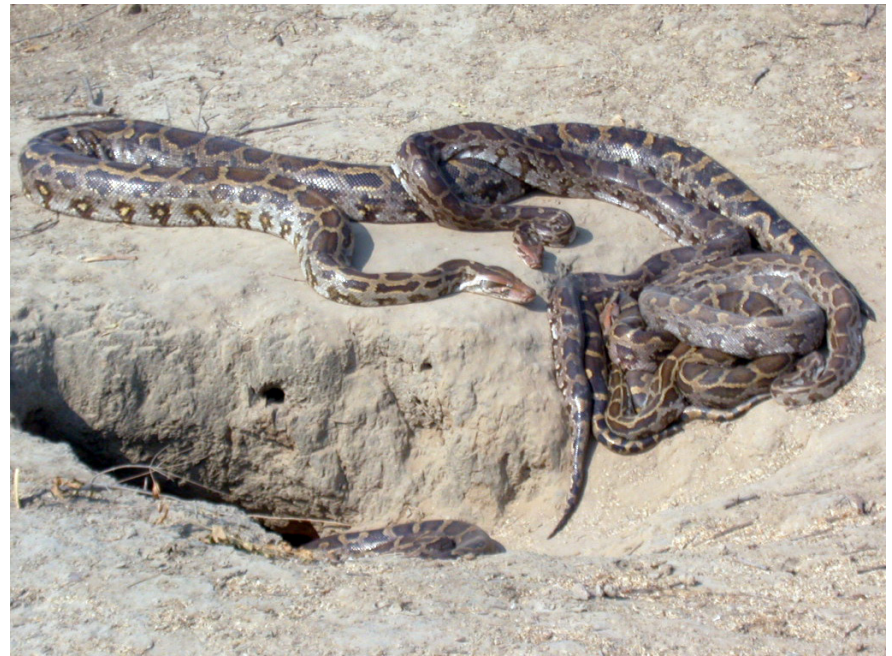

Fig. 3. An aggregation of Indian Pythons (Python molurus) basking at the burrow entrance during winter in Keoladeo National Park, Rajasthan, India. Photograph by Chinnasamy Ramesh.

(tracks, sloughed skin, scats) were observed at or near an entrance (Krishnan et al. 2009; Fig. 2). We focused our observations on one burrow (J, Fig. 1) where we had encountered the greatest number of pythons (Fig. 3). Using a digital thermometer (Eurolab 288-ATH; HTC Instruments, Mumbai, India), we recorded diurnal ambient temperatures $1 \mathrm{~m}$ above the ground and burrow temperatures with a thermistor probe that was inserted $3 \mathrm{~m}$ into the burrow at 15 -min intervals.

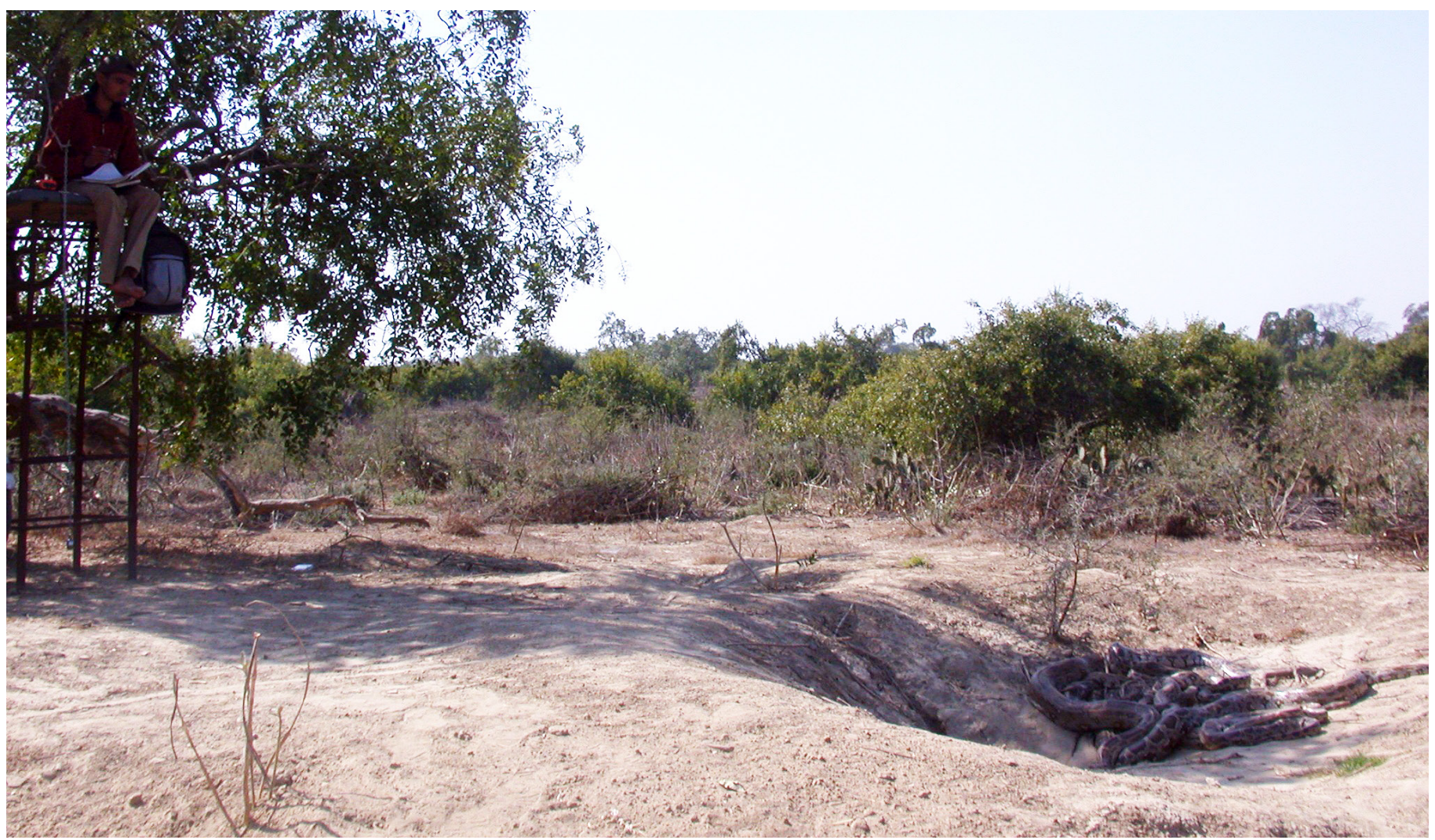

Fig. 4. Observing Indian Python (Python molurus) activity in Keoladeo National Park, Rajasthan, India. Photograph by Chinnasamy Ramesh. 
Table 1. Number of snakes observed outside the burrow during each observation day in the sampled periods during December 2008 through May 2009.

\begin{tabular}{|c|c|c|c|c|c|c|c|c|c|c|}
\hline \multirow[b]{2}{*}{ Day } & \multicolumn{3}{|c|}{ Winter } & \multicolumn{4}{|c|}{$\begin{array}{c}\text { Season } / \text { Period } \\
\text { Spring }\end{array}$} & \multicolumn{3}{|c|}{ Summer } \\
\hline & I & II & III & IV & V & VI & VII & VIII & IX & $\mathrm{X}$ \\
\hline 1 & 4 & 11 & 16 & 15 & 19 & 13 & 4 & 1 & 0 & 0 \\
\hline 2 & 12 & 25 & 17 & 17 & 16 & 6 & 0 & 0 & 0 & 0 \\
\hline 5 & 12 & 14 & 16 & 8 & 17 & 13 & 2 & 4 & 0 & 0 \\
\hline 6 & 10 & 11 & 18 & 11 & 17 & 1 & 0 & 2 & 0 & 0 \\
\hline 7 & 11 & 18 & 14 & 13 & 15 & 13 & 8 & 1 & 0 & 0 \\
\hline
\end{tabular}

Every fortnight from December 2008 through May 2009, we monitored the burrow from 0600 to $1800 \mathrm{~h}$ for seven consecutive days from a concealed 2-m high platform placed $-3 \mathrm{~m}$ from the burrow under a Mustard Tree thicket (Fig. 4). We divided observations into ten periods (each 7-day sequence $=$ one period) categorized as winter, spring, and summer (Table 1). During the summer when pythons were crepuscular, we based ingress and egress from burrows on signs. We identified each individual based on dorsal markings, color, and size (Bhupathy 1990).

Because basking is the predominant activity during the winter (December-February), with courtship, mating, and foraging activities usually beginning in March (Ramesh 2012), to differentiate basking and other activities we recorded basking duration only in the winter months. For each observation of ingress or egress, we recorded time, ambient temperature, and humidity. For all observations of pythons outside of the burrow, we recorded activity, time, ambient temperature, and humidity. We used analysis of variance (ANOVA) to test differences in activities during various periods and Pearson correlation to evaluate relationships between activities and environmental variables. Means are presented \pm one standard deviation (SD).

\section{Results}

During November to February, ambient temperatures varied from 19.98 to $29.43{ }^{\circ} \mathrm{C}\left(30.82 \pm 5.64{ }^{\circ} \mathrm{C}\right)$. Mean ambient temperature was above $32^{\circ} \mathrm{C}\left(32.33-37.42^{\circ} \mathrm{C}\right)$ from March through September (Fig. 5). The highest ambient temperature recorded was in May $\left(37.4^{\circ} \mathrm{C}\right)$ and the lowest in December $\left(19.97^{\circ} \mathrm{C}\right)$. Mean burrow temperature was $23.68 \pm 5.05^{\circ} \mathrm{C}$ (17.3-30.5 ${ }^{\circ} \mathrm{C}$; Fig. 5). Variation in ambient temperatures was $8.57-38.47^{\circ} \mathrm{C}$, much greater than that recorded in burrows $\left(0.65-5.13^{\circ} \mathrm{C}\right.$; Fig. 5$)$.
During the 10 periods, we recorded 568 observations of pythons basking, with the largest number (109) in February and the fewest (11) in the first period of April (Table 1). After late April, we recorded no activities. The mean number of pythons found outside the burrow during any given period varied from 1.6 to $15.6 \pm 4.0$, with the number varying little (89 to 109 ) from December through February. Basking activity varied significantly by period $(\mathrm{F}=10.636 ; \mathrm{df}=7,55 ; \mathrm{P}<0.001)$. The number of pythons observed was positively correlated with ambient temperature $(\mathrm{r}=0.767, \mathrm{P}=0.003)$ and negatively correlated with relative humidity $(\mathrm{r}=-0.748, \mathrm{P}>0.02)$.

We recorded no activity on days 44, 46, 48, 51, and 52 and during the last three periods. Frequencies of observations decreased along the winter-summer gradient (Fig. 6). Most basking activity was recorded at 1200-1400 $\mathrm{h}$ in winter (December-January) and spring (February-March). Activity in summer was low and extended through most of the day with slight peaks at 1000-1200 and 1600-1800 h (activity index $=$ N/20; Fig. 6). Activity was unimodal in winter and spring, with peaks at 1200-1400 h and 1000-1400 h, respectively. In summer, activity was bimodal, with peaks at

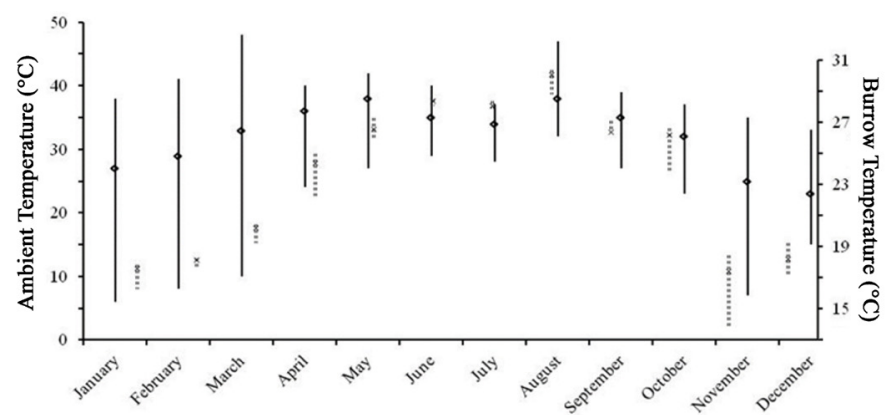

Fig. 5. Monthly variation in ambient temperatures (solid lines) and burrow temperatures (dashed lines) recorded in October 2008 through September 2009 in Keoladeo National Park, Rajasthan, India. 


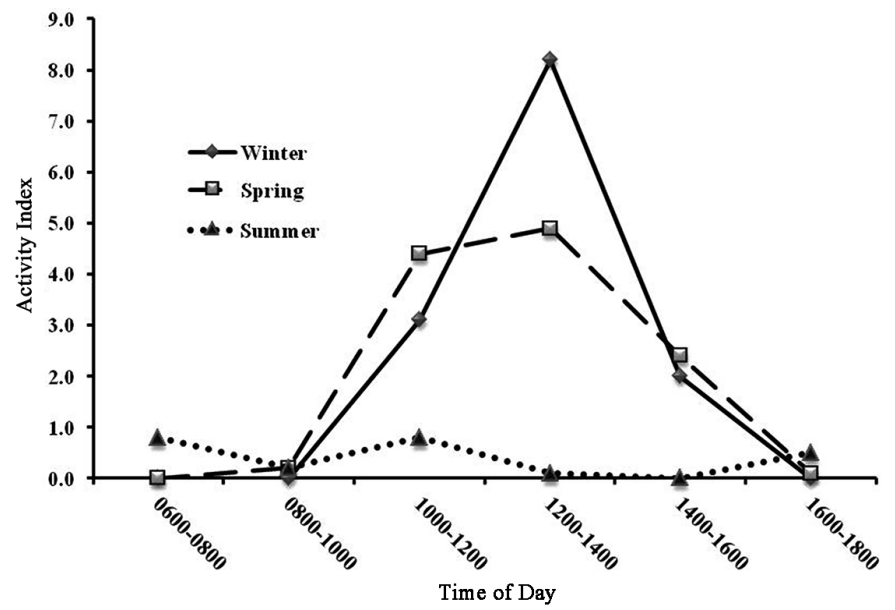

Fig. 6. Basking activity index of Indian Pythons (Python molurus) in Keoladeo National Park, Rajasthan, India.

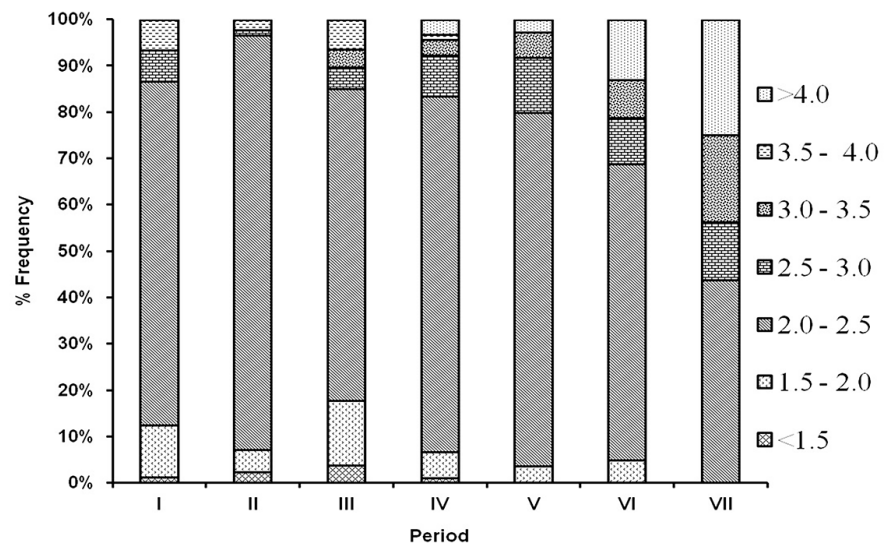

Fig. 7. Various size classes (m) of Indian Pythons (Python molurus) observed in different seasons at the burrow in Keoladeo National Park, Rajasthan, India.

1000-1200 h and 1600-1800 h. During winter and spring, we recorded egress only after $0930 \mathrm{~h}$; during summer, most observations of egress were recorded in the early morning (0600-0800 h).

During the course of the study, we recorded 29 different individuals that ranged in size from 1.3 to $4.2 \mathrm{~m}$. Of the 568 observations, most snakes $(432 ; 76 \%)$ measured between 2.0 and $2.5 \mathrm{~m}$ in length $(76 \%)$ and the fewest $(6 ; 1 \%)$ measured $<1.5 \mathrm{~m}$ in length. Basking activity differed by size across seasons (Fig. 7), with smaller snakes $(<1.5-2.0 \mathrm{~m})$ observed only in winter months when larger pythons $(>4.0 \mathrm{~m})$ were not active. Snakes with lengths of about $2.5 \mathrm{~m}$ were most active in December through April, large pythons $(>4.0 \mathrm{~m})$ in March and April, and juveniles $(<1.5 \mathrm{~m})$ only in December and January. Activity of snakes of various sizes differed significantly by season $(\mathrm{F}=5.399 ; \mathrm{df}=2,6 ; \mathrm{p}<0.001)$.

Only a few individuals were active for any extended periods (Fig. 8). The most active snake $(2.43 \mathrm{~m})$ was observed leaving the burrow 65 times. Generally, basking increased as winter approached and decreased with the onset of summer. During winter, the earliest egress recorded was at 0930 $\mathrm{h}$ and the latest at $1550 \mathrm{~h}$. Mean egress time was $1245 \mathrm{~h}$, most occurred between 1230 and $1430 \mathrm{~h}$ when the mean temperature was $35.4 \pm 5.8^{\circ} \mathrm{C}\left(18.1-42.9^{\circ} \mathrm{C}\right)$. The most frequently recorded temperature at egress was $40^{\circ} \mathrm{C}$ followed by $38^{\circ} \mathrm{C}$. Fewer snakes emerged when the ambient temperature was $<34{ }^{\circ} \mathrm{C}$ and more when it was $>40{ }^{\circ} \mathrm{C}$ (Fig. 9), when relative humidity ranged from 20 to $96 \%(33 \pm 22 \%)$. Most (341) individuals emerged when humidity was relatively low (<30\%; Fig. 10) and very few emerged during periods when humidity was higher. The earliest ingress was recorded at $1050 \mathrm{~h}$ and the latest at $1630 \mathrm{~h}$, with the greatest number occurring between 1330 and $1430 \mathrm{~h}$ in December through February. Overall, more than $50 \%$ of observations of ingress were between 1230 and $1500 \mathrm{~h}$. At ingress, the average ambient temperature was $36.2 \pm 4.7^{\circ} \mathrm{C}\left(18.8-4.1^{\circ} \mathrm{C}\right)$, with most snakes entering the burrow at a temperature of about $40{ }^{\circ} \mathrm{C}$ and only a few at temperatures $<34^{\circ} \mathrm{C}$ (Fig. 6). Mean relative humidity at ingress was $29.1 \pm 17.9 \%$, with the highest (211) and lowest (6) numbers of observations at relative humidity of $30 \%$ and $80 \%$, respectively (Fig. 7 ).

\section{Discussion}

The strong relation between basking frequency and season, with a notably higher frequency observed during colder months, when pythons restricted their movements to the immediate vicinity of the burrow, was similar to findings of Landreth (1973) and Dalrymple et al. (1991). Also, the aggregation of pythons at the burrow could help maintain body temperatures by heat retention (i.e., Myres and Eells 1968) and might reduce water loss (i.e., Parker and Plummer 1987).

Python molurus prepares for reproductive activities in the late winter (Ramesh and Bhupathy 2010), and Carriere et al. (2008) noted the importance of behavioral thermoregulation in reptiles prior to reproduction. Basking activity increased from December to February, whereas ingress and egress activity decreased along the winter-summer gradient. This was similar to observations of Common Sand Boas (Eryx conicus) by Griffiths (1984) and in another study of Python molurus in KNP (Bhatt and Choudhury 1993). These trends, however, differ substantially from those reported in lizards (e.g., Ellinger et al. 2001; Burke and Ner 2005) and small-bodied snakes (Landreth 1973; Sanders and Jacob 1980; Semlitsch et al. 1981; Secor 1994; Chettri et al. 2009), in which activity was high in the summer and low in winter. Variation in activity between large snakes and small reptiles could be attributable to differences in their thermal preferences, movements, energy requirements, or breeding strategies. Shine (1979) found that the determining factors for activity pattern in snakes were species-specific and likely are a reflection of a combination of ecological, physiological, and evolutionary factors. 


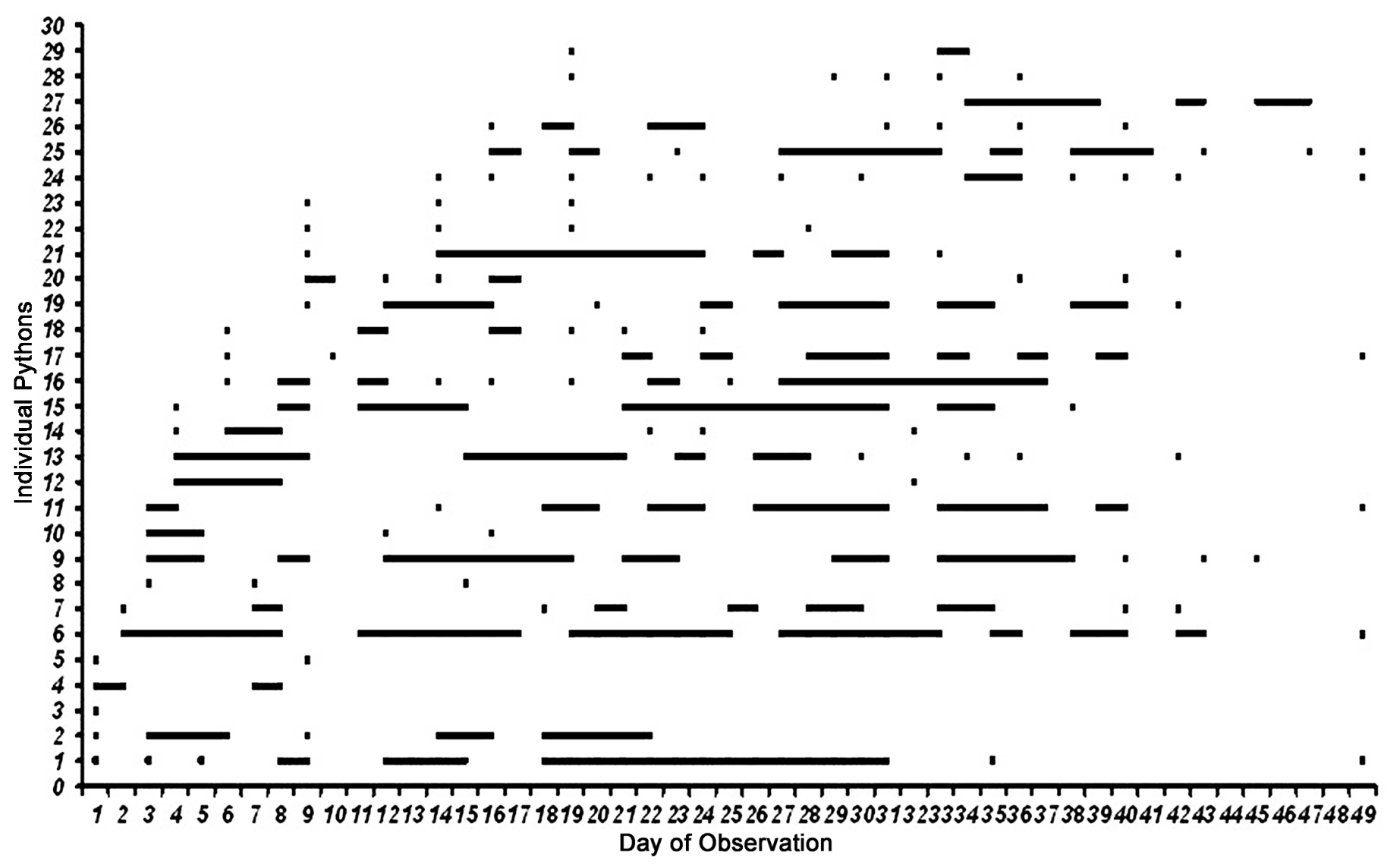

Fig. 8. Egress and ingress of 29 Indian Pythons (Python molurus) over 49 days of observation (22 December 2008-14 May 2009; Periods I-VII) showing the increased frequency of observations during the winter-summer gradient.

Pythons in KNP become crepuscular and then nocturnal beginning in mid-April, a pattern similar to that described by Platt (1969) and Sanders and Jacob (1980) for temperate snakes and by Slip and Shine (1988) and Shine and Fitzgerald (1996) for tropical Diamond Pythons (Morelia spilota). Increasing crepuscular or nocturnal activity during summer likely reflect a need to avoid high daytime temperatures.

Pythons of medium size $(2.0-2.5 \mathrm{~m})$ were most active in all seasons, with smaller snakes $(<2.0 \mathrm{~m})$ more active in early winter and large snakes $(>4.0 \mathrm{~m})$ most active during late winter and summer. Pythons with SVL $>2.5 \mathrm{~m}$ are sexually mature (Acharjyo and Misra 1976), and the more frequent and extended periods of activity we observed during spring and summer probably reflect reproductive activities. Mating generally occurs in late February, ovipositioning in May, and incubation and hatching in June through August (Bhupathy and Vijayan 1989; Ramesh and Bhupathy 2010). In northern India, mating in Python molurus has been reported from late winter and spring (i.e., February to early April) by Whitaker (1978) and Acharjyo and Misra (1976). During this time, smaller pythons would have become nocturnal and moved out of burrows to forage. A similar pattern was reported for juvenile Broad-headed Snakes (Hoplocephalus bungaroides) by Webb and Whiting (2005).

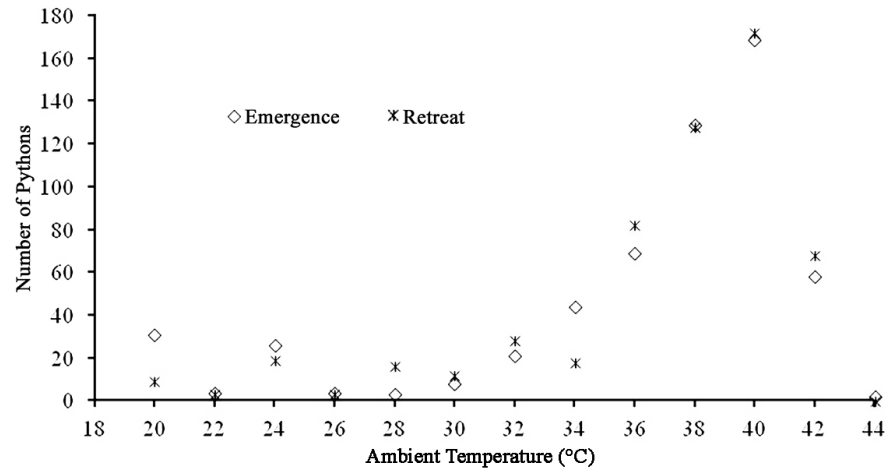

Fig. 9. Rates of egress and ingress of Indian Pythons (Python molurus) at varying ambient temperatures.

Early morning egress does not occur during winter and spring, probably in response to cold conditions during the morning hours. Earlier emergence in late spring and summer suggests that pythons are not active below and above certain temperature regimes, a pattern reported for a number of reptilian species (e.g., Semlitsch et al. 1981; Díaz-Paniagua et al. 1995; Zari 1996; Gibbons and Semlitsch 1997). Higher rates of ingress and egress were observed at moderate levels of relative humidity. Relative humidity can affect desiccation rates of snakes (Heatwole 1976; Lillywhite 1980), but 


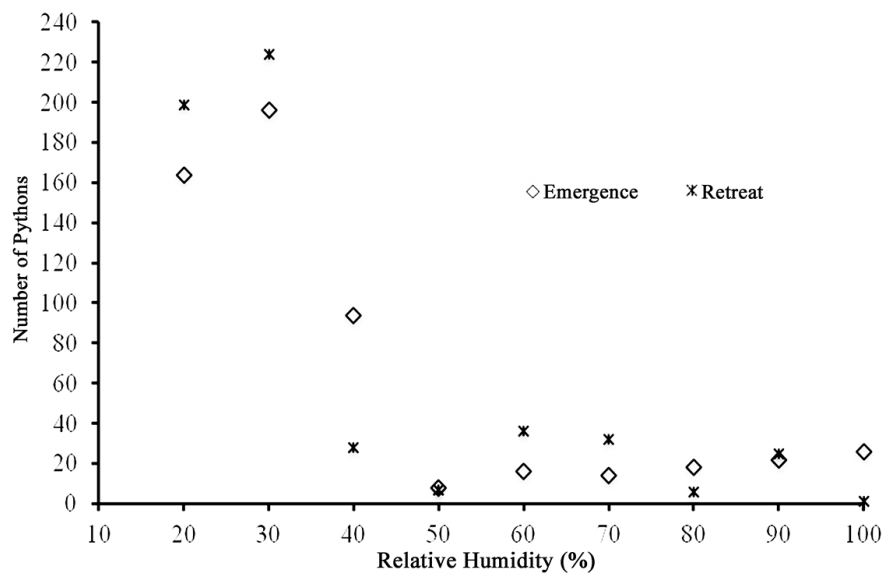

Fig. 10. Rates of egress and ingress of Indian Pythons (Python molurus) at varying relative humidity levels.

humidity generally does not appear to correlate with snake activity (Stewart 1965; Shine and Lambeck 1985). However, low humidity combined with high temperature might trigger retreat into refugia (e.g., Bhatt and Choudhury 1993).

Burmese Pythons (Python bivittatus) in more temperate regions appear to brumate in the winter (e.g., Reed and Rodda 2009), whereas the pythons at KNP are sometimes inactive in refugia for extended periods. Many factors influence the basking pattern such as reproductive status, age, ecdysis and feeding before the onset of winter (Ramesh and Bhupathy 2010, 2013; Bhupathy et al. 2014).

We suggest that regulating the number of visitors in KNP and at other locations within the range of Python molurus might be advisable in order to avoid disturbing snakes during periods when activity is limited. Interference with behaviors at those times could affect the thermal profile of the species, which in turn could affect the growth, feeding, and breeding activity. Further studies employing temperature-sensitive radio telemetry could provide additional insights on Indian Pythons in natural habitats.

\section{Acknowledgements}

This paper is an outcome of research projects sponsored by DST-SERB (EMR/2016/003963), Government of India and the Ministry of Environment and Forests (20-28/2005/WL), Government of India. We thank the late Dr. S. Bhupathy for his guidance and constant support throughout the study. We record our heartfelt thanks to the PCCF and Chief Wildlife Warden, Rajasthan, and Directors of the Keoladeo National Park (Sunayan Sharma, Rajesh Gupta, and K.R. Anoop) for permission to work in the park and for logistical support in the field. We also thank Malvika Onial, Anant Pande, Ridhima Solanki, and Biba Jasmine for suggestions and support. Babu (SACON) helped us prepare the map, and Randhir Singh assisted us during fieldwork. We thank the directors of WII, ZSI, and SACON for encouragement.

\section{Literature Cited}

Acharjyo, L.N. and R. Misra. 1976. Aspects of reproduction and growth of the Indian Python (Python molurus molurus) in captivity. British Journal of Herpetology 5: 562-565.

Alexander, G.J. 2007. Thermal biology of the Southern African Python (Python natalensis): Does temperature limit its distribution?, pp. 50-75. In: R.W. Henderson and R. Powell (eds.), Biology of the Boas and Pythons. Eagle Mountain Publishing, Eagle Mountain, Utah.

Avery, R.A. 1982. Field studies of body temperatures and thermoregulation, pp. 93-146. In: C. Gans and F.H. Pough (eds.), Biology of the Reptilia. Volume 12. Physiology C. Physiological Ecology. Academic Press, London, UK.

Bhatt, K. and B.C. Choudhury. 1993. The diel activity pattern of Indian python (Python molurus molurus) at Keoladeo National Park, Bharaptur, Rajasthan. Journal of the Bombay Natural History Society 90: 394-403.

Bhupathy, S. 1990. Blotch structure in individual identification of the Indian python (Python molurus molurus) and its possible usage in population estimation. Journal of the Bombay Natural History Society 87: 399-404.

Bhupathy, S. and V.S. Vijayan.1989. Status, distribution and general ecology of the Indian Python (Python molurus molurus) in Keoladeo National Park, Bharatpur, Rajasthan. Journal of the Bombay Natural History Society 86: 381-387.

Bhupathy, S., C. Ramesh, and A. Bahuguna. 2014. Feeding habits of Indian Rock Pythons in Keoladeo National Park, Bharatpur, India. The Herpetological Journal 24: 59-64.

Bonnet, X., G. Naulleau, and R. Shine. 1999. The dangers of leaving home: Dispersal and mortality in snakes. Biological Conservation 89: 39-50.

Brashears, J. and D. Denardo. 2015. Facultative thermogenesis during brooding is not the norm among pythons. Journal of Comparative Physiology 201: 817-825.

Brattstrom, B.H. 1965. Body temperatures of reptiles. American Midland Naturalist 73: 376-422.

Brown, G.P. and P.J Weatherhead. 2000. Thermal ecology of Northern Water Snakes, Nerodia sipedon. Ecological Monographs 70: 311-330.

Brown, G.P. and R. Shine. 2002. Influence of weather conditions on activity of tropical snakes. Austral Ecology 27: 596-605.

Burke, R.L. and S.E. Ner. 2005. Seasonal and diel activity patterns of Italian Wall Lizards, Podarcsis sicula campestris, in New York. Northeastern Naturalist 12: 349-360.

Carriere, M.A., N. Rollinson, A.N. Suley, and R.J. Brooks. 2008. Thermoregulation when the growing season is short: Sex-biased basking patterns in a northern population of Painted Turtles (Chrysemys picta). Journal of Herpetology 42: 206-209.

Chettri, B., S. Bhupathy, and B.K. Acharya. 2009. Morphometry and aspects of breeding biology of Trachischium guentheri Boulenger, 1890 (Serpentes: Colubridae) in North Sikkim, Eastern Himalaya, India. Russian Journal of Herpetology 16: 177-182.

Dalrymple, G.H., T.M. Steiner, R.J. Nodell, and F.S. Bernardino. 1991. Seasonal activity of the snakes of Long Pine Key, Everglades National Park. Copeia 1991: 294-302.

Díaz-Paniagua, C., C. Keller, and A.C. Andreu. 1995. Annual variation of activity and daily distances moved in adult Spur-thighed Tortoises, Testudo graeca, in southwestern Spain. Herpetologica 51: 225-233.

Ellinger, N., G. Schlatte, N. Jerome, and W. Hödl. 2001. Habitat use and acitivty patterns of the Neotropical arboreal lizard Tropidurus (= Uracentron) azureus werneri (Tropiduridae). Journal of Herpetology 35: 395-402.

Gibbons, J.W. and R.D. Semlitsch. 1997. Activity patterns, pp. 396-421. In: R.A. Seigel, J.T. Collins, and S.S. Novak (eds.), Snakes: Ecology and Evolutionary Biology. Macmillan Publication Company, New York, New York.

Griffiths, R.A. 1984. The influence of light and temperature on diel activity rhythms in the Sand Boa, Eryx conicus. Journal of Herpetology 18: 374-380.

Harker, J.E. 1958. Diurnal rhythms in the animal kingdom. Biological Review 33: $1-52$.

Heard, G.W., D. Black, and P. Robertson. 2004. Habitat use by the inland carpet python (Morelia spilota metcalfei: Pythonidae): seasonal relationships with habitat structure and prey distribution in a rural landscape. Austral Ecology 29: 446-460.

Heatwole, H. 1976. Reptile Ecology. University of Queensland Press, St. Lucia, Australia. 
Huey, R.B. 1982. Temperature, physiology and the ecology of reptiles, pp. 25-96. In: C. Gans and F.H. Pough (eds.), Biology of the Reptilia. Volume 12. Physiology C. Physiological Ecology. Academic Press, London, UK.

Huey, R.B., E.R. Pianka, and J.A. Hoffman. 1977. Seasonal variation in thermoregulatory behavior and body temperature of diurnal Kalahari lizards. Ecology 58: 1066-1075.

Hutchison, V.H. and J.D. Maness. 1979. The role of behaviour acclimation and tolerance in ectotherms. American Zoologist 19: 367-384.

Kamalakannan, M. 2009. Diurnal activity of Indian Rock Python, Python molurus molurus Linn. (1758) in Keoladeo National Park, Bharatpur, Rajasthan, India. Unpublished M. Phil. Thesis, Bharathiar University, Coimbatore, India.

Krishnan, S., S. Bhupathy, and K.V. Devi Prasad. 2009. Monitoring of Python molurus molurus in Keoladeo National Park. Bharatpur, Rajasthan. Hamadryad34: 28-33.

Landreth, H.F. 1973. Orientation and behavior of the Rattlesnake, Crotalus atrox. Copeia 1973: 26-31.

Lillywhite, H.B. 1980. Behavioral thermoregulation in Australian Elapid Snakes. Copeia 1980: 452-458.

Lillywhite, H.B. 1987. Temperature, energetics, and physiological ecology, pp. 422477. In: R.A. Seigel, J.T. Collins, and S.S. Novak (eds.), Snakes: Ecology and Evolutionary Biology. Macmillan Publication Company, New York, New York.

Mazzotti, F.J., M.S. Cherkiss, K.M. Hart, R.W. Snow, M.R. Rochford, M. E. Dorcas, and R.N. Reed. 2011. Cold-induced mortality of invasive Burmese Pythons in south Florida. Biological Invasions 13: 143-151.

Madsen, T. and R. Shine. 1998. Quantity or quality? Determinants of maternal reproductive success in tropical pythons (Liasis fuscus). Proceedings of the Royal Society of London B 265: 1521-1525.

Myres, B.C. and M.M. Eells. 1968. Thermal aggregation in Boa constrictor. Herpetologica 24: 61-66.

Parker, W.S. and M.V. Plummer. 1987. Population ecology, pp. 253-301. In: R.A. Seigel, J.T. Collins, and S.S. Novak (eds.), Snakes: Ecology and Evolutionary Biology. Macmillan Publication Company, New York, New York.

Platt, K.R. 1969. Natural history of the hognose snakes Heterodon platyrhinos and Heterodon nasicus. University of Kansas Publications, Museum of Natural History 18: 253-420.

Porter, W.P., J.W. Mitchell, W.A. Beekman, and C.B. DeWitt. 1973. Behavioral implications of mechanistic ecology: Thermal and behavioral modeling of desert ectotherms and their microenvironment. Oecologia 13: 1-54.

Prasad, V.P., D. Mason, J.E. Marburger, and C.R. Ajithkumar. 1996. Illustrated Flora of Keoladeo National Park, Bharatpur, Rajasthan: A General Guide to the Wetland Flora of the Gangetic Plains. Bombay Natural History Society and Oxford University Press India, Mumbai, India.

Prusty, B.A.K., P.A. Azeez, and E.P. Jagadeesh. 2007. Alkali and transition metals in macrophytes of a wetland system. Bulletin of Environmental Contamination and Toxicology 78: 405-410.

Ramesh, C. 2012. Ecology of Indian rock python Python molurus molurus (Linn. 1758) in Keoladeo National Park, Bharatpur, Rajasthan, India. Unpublished Ph.D. Thesis, Bharathiar University, Coimbatore, India.

Ramesh, C. and S. Bhupathy. 2010. Breeding biology of Python molurus molurus in
Keoladeo National Park, Bharatpur, India. Herpetological Journal 20: 157-163.

Ramesh, C. and S. Bhupathy. 2013. Ecdysis in free-ranging Indian rock pythons: a case study. Hamadryad 36: 130-136.

Reed, R.N. and G.H. Rodda. 2009. Giant constrictors: Biological and Management Profiles and an Establishment Risk Assessment for Nine Large Species of Pythons, Anacondas, and the Boa Constrictor. Open-File Report 2009-1202. U.S. Geological Survey, Fort Collins, Colorado.

Rismiller, P.D. and G. Heldmaier. 1988. How photoperiod influences body temperature selection in Lacerta viridis. Oecologia 75: 125-131.

Sanders, J.S. and J.S. Jacob. 1980. Thermal ecology of the Copperhead (Agkistrodon contortrix). Herpetologica 37: 264-270.

Secor, S.M. 1994. Ecological significance of movements and activity range for the Sidewinder, Crotalus cerastes. Copeia 1994: 631-645.

Semlitsch, R.D., K.L. Brown, and J.P. Caldwell. 1981. Habitat utilization, seasonal activity, and population size structure of the Southeastern Crowned Snake Tantilla coronata. Herpetologica 37: 40-46.

Shine, R. 1979. Activity patterns in Australian elapid snakes (Squamata: Serpentes: Elapidae) Herpetologica 35: 1-11.

Shine, R. and M. Fitzgerald. 1996. Large snakes in a mosaic rural landscape: The ecology of carpet pythons Morelia spilota (Serpentes: Pythonidae) in coastal eastern Australia. Biological Conservation 76: 113-122.

Shine, R. and R. Lambeck. 1985. A radiotelemetric study of movements, thermoregulation and habitat utilization of Arafura Filesnakes (Serpentes: Acrochordidae). Herpetologica 41: 351-361.

Slip, D.J. and R. Shine. 1988. Reptilian endothermy: a field study of thermoregulation by brooding diamond pythons. Journal of Zoology 216: 367-378.

Stahlschmidt, Z.R. and D.F. DeNardo. 2010. Parental behavior in pythons is responsive to both the hydric and thermal dynamics of the nest. Journal of Experimental Biology 213: 1691-1696.

Stahlschmidt Z.R., R. Shine, and D.F. DeNardo. 2012. Temporal and spatial complexity of maternal thermoregulation in tropical pythons. Physiological and Biochemical Zoology 85: 219-230.

Stewart, G.R. 1965. Thermal ecology of the garter snakes Thamnophis sirtalis concinnus (Hallowell) and Thamnophis ordinoides (Baird and Girard). Herpetologica 21: 81-102.

Webb, J.K. and M.J. Whiting. 2005. Why don't small snakes bask? Juvenile broadheaded snakes trade thermal benefits for safety. Oikos 110: 515-522.

Werner, Y.L., H. Takahashia, W.J. Mautz, and H. Otaa. 2005. Behavior of the terrestrial nocturnal lizards Goniurosaurus kuroiwae kuroiwae and Eublepharis macularius (Reptilia: Eublepharidae) in a thigmothermal gradient. Journal of Thermal Biology 30: 247-254.

Whitaker, R. 1978. Common Indian Snakes. A Field Guide. Macmillan Publishers India Ltd., Noida, Uttar Pradesh, India.

Withers, P.C. 1992. Comparative Animal Physiology. Saunders College Publishing, New York, New York.

Zari, T.A. 1996. Activity body temperature and diel variation of metabolic rate in the nocturnal gecko, Hemidactylus turcicus (Reptilia: Geckkonidae). Journal of King Abdulaziz University-Science 8: 35-44. 